\title{
Low Density Lipoprotein-oxidation Inhibitory Phytochemicals from the Fruits of Rhus parviflora
}

\author{
Sabina Shrestha $\cdot$ Ji-Hae Park $\cdot$ Jin-Gyeong Cho $\cdot$ Dae-Young Lee $\cdot$ Ji-Hyun Kang $\cdot$ \\ Hua Li - Tae-Sook Jeong • Somi Kim Cho · Dong-Sun Lee · Nam-In Baek*
}

Received: 3 January 2015 / Accepted: 23 January 2015 / Published Online: 30 June 2015

(C) The Korean Society for Applied Biological Chemistry 2015

\begin{abstract}
Fruits of Rhus parviflora were extracted with $80 \%$ aqueous methanol $(\mathrm{MeOH})$, and the concentrated extract was partitioned using ethyl acetate (EtOAc), $n$-butanol $(n-\mathrm{BuOH})$, and $\mathrm{H}_{2} \mathrm{O}$, successively. Purification of EtOAc fraction led to isolation of fifteen polyphenols of which structures were identified by spectroscopic methods including 2D-NMR. Most compounds apart from compound $\mathbf{1 0}$ inhibited low density lipoproteinoxidation within $\mathrm{IC}_{50}$ value of $10 \mu \mathrm{M}$. Among compounds, taxifolin (2), quercetin 3-O- $\alpha$-L-rhamnopyranoside (13), agathisflavone (5) sulfuretin (4), and aureusidin (3) showed $\mathrm{IC}_{50}$ values $0.9,0.8,5.8$, 2.9 , and $2.4 \mu \mathrm{M}$ which were of highly significant in comparison positive control butylated hydroxytoluene with $\mathrm{IC}_{50}$ value of 2.1 $\mu \mathrm{M}$. The results indicate fruits of $R$. parviflora as a source of antihypercholesterolemic compounds.
\end{abstract}

Keywords anacardiaceae $\cdot$ anti-hypercholesterolemic $\cdot$ aurone $\cdot$ biflavonoid $\cdot$ low density lipoprotein-oxidation $\cdot$ Rhus parviflora

S. Shrestha $\cdot$ J.-H. Park · J.-G. Cho $\cdot$ N.-I. Baek

Graduate School of Biotechnology, Institute of Life Science and Resources, Kyung Hee University, Yongin 446-701, Republic of Korea

D.-Y. Lee

Department of Medicinal Crop Research, National Institute of Horticultura and Herbal Science, Rural Development Administration, Eumseong 369873 , Republic of Korea

J.-H. Kang $\cdot$ H. Li $\cdot$ T.-S. Jeong

National Research Laboratory of Lipid Metabolism \& Atherosclerosis, KRIBB, Daejeon 305-806, Republic of Korea

S. Shrestha $\cdot$ S. K. Cho $\cdot$ D.-S. Lee

Faculty of Biotechnology, College of Applied Life Sciences, Jeju National University, Jeju 690-756, Republic of Korea

*Corresponding author (N.-I. Baek: nibaek@khu.ac.kr)

This is an Open Access article distributed under the terms of the Creative Commons Attribution Non-Commercial License (http://creativecommons. org/licenses/by-nc/3.0/) which permits unrestricted non-commercial use, distribution, and reproduction in any medium, provided the original work is properly cited.
R. parviflora Roxb. (Aanacardiaceae) is a sub-deciduous shrub of south Asia with distribution in Nepal, northern India, Bhutan and Sri Lanka (Press et al., 2000). Its edible berries which get ripe in December-February are used in Ayurvedic medicine for curing neurological and stomach disorders (Anonymous, 2006). We reported previously cytotoxic (Shrestha et al., 2012c), anti-insomnia (Shrestha et al., 2012b), neuroprotective (Shrestha et al. 2012a; 2013a; 2013c), anti-inflammatory (Shrestha et al. 2013b) properties of compounds from $R$. parviflora fruit. In this study we further evaluated the compounds for their low-density lipoprotein (LDL)oxidation inhibition capacity.

Cardiovarsular disease is one of the leading causes of mortality with toll of 16.7 million deaths per year (Dahlöf, 2010). The oxidation of LDL is an early pathological process of atherosclerosis (Glass and Witztum, 2001). LDL particles are trapped in the intima, undergoes oxidative modifications caused by enzymatic attack of myeloperoxidase and lipoxygenases, or by reactive oxygen species during inflammation and atherosclerosis (Hansson and Hermansson, 2011).

The air-dried fruits $(6 \mathrm{~kg})$ of $R$. parviflora were extracted at room temperature in $80 \%$ aqueous $\mathrm{MeOH}(25 \mathrm{~L} \times 3)$ for $24 \mathrm{~h}$ gave concentrated extract $(1440 \mathrm{~g})$. The $\mathrm{MeOH}$ extract was suspended in distilled $\mathrm{H}_{2} \mathrm{O}(6 \mathrm{~L})$ and successively partitioned with EtOAc $(6 \mathrm{~L} \times 3)$ and $n$ - $\mathrm{BuOH}(6 \mathrm{~L} \times 3)$, to obtain concentrated extracts in the EtOAc (RPE, $48 \mathrm{~g}$ ), $n$-BuOH (RPB, $173 \mathrm{~g}$ ), and $\mathrm{H}_{2} \mathrm{O}$ (RPW, $1219 \mathrm{~g})$ fractions.

The concentrated EtOAc fraction (RPE, $48 \mathrm{~g}$ ) was applied to silica gel column chromatography (c.c.) $(\phi 14 \times 12 \mathrm{~cm})$ and eluted with $n$-hexane-EtOAc [(10:1 $\rightarrow 3: 1 \rightarrow 1: 1,20 \mathrm{~L}$ of each) and $\mathrm{CHCl}_{3}$ $\mathrm{MeOH}(6: 1 \rightarrow 1: 1,10 \mathrm{~L}$ each)], gave 22 fractions. Fraction RPE13 [2.41 g, elution volume/total volume $\left(\mathrm{V}_{\mathrm{e}} / \mathrm{V}_{\mathrm{t}}\right)$ 0.59-0.80] was subjected to a Sephadex LH-20 c.c. $(\phi 2.5 \times 45 \mathrm{~cm})$, and eluted with $\mathrm{MeOH}-\mathrm{H}_{2} \mathrm{O}(2: 1,500 \mathrm{~mL} \rightarrow 2: 1,1.5 \mathrm{~L})$ isolated fustin, (1) at RPE-13-6 [15.5 mg, $\mathrm{V}_{\mathrm{e}} / \mathrm{V}_{\mathrm{t}}$ 0.02-0.04, TLC (RP-18 $\left.\mathrm{F}_{254} \mathrm{~s}\right) R_{f} 0.87$, in $\left.\mathrm{MeOH}-\mathrm{H}_{2} \mathrm{O}(3: 1)\right]$ and taxifolin (2) at RPE-13-7 [30.0 mg, $\mathrm{V}_{\mathrm{e}} / \mathrm{V}_{\mathrm{t}}$ 0.04-0.07, TLC (RP-18 $\left.\mathrm{F}_{254} \mathrm{~s}\right) R_{f} 0.85$, in $\left.\mathrm{MeOH}-\mathrm{H}_{2} \mathrm{O}(3: 1)\right]$, 


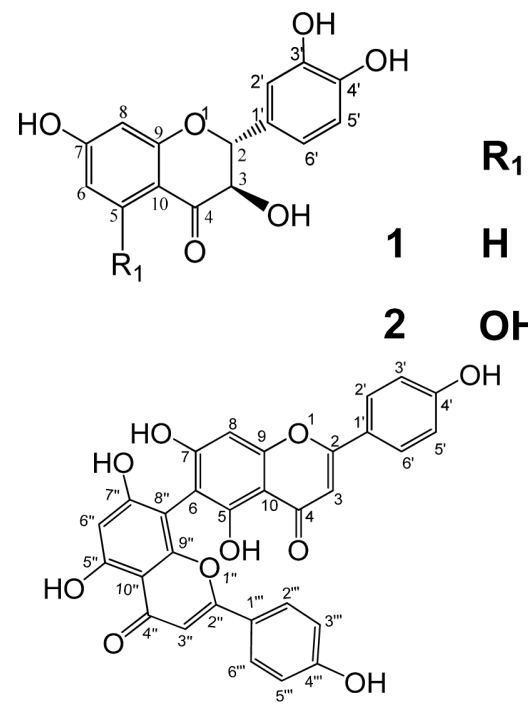

5<smiles></smiles>

8<smiles>[R6]Oc1cc(O)c2c(=O)c([R2])c(-c3ccc(O)c(OCC)c3)oc2c1</smiles><smiles></smiles>

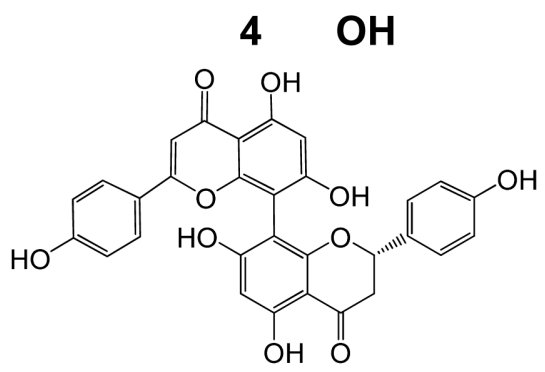

7

6<smiles>O=C1C=C(O)C2=C(O)C=C(O[C@H](c3ccc(O)cc3)C1)C(c1ccc(O)cc1)CC(=O)C1Oc3c(O)cc(O)c2c3O1</smiles>

9

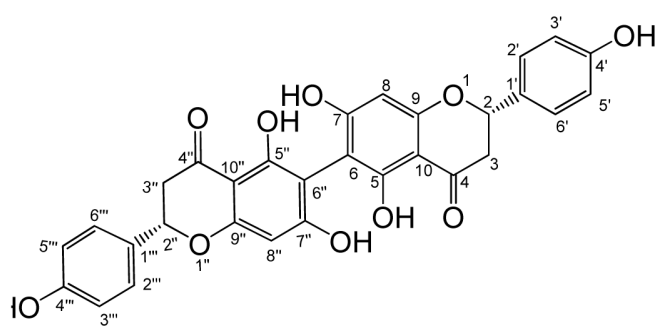

10

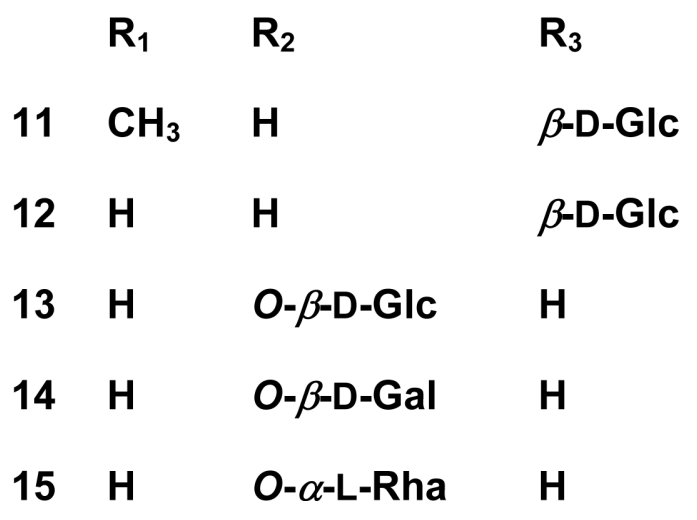

Fig. 1 Chemical structures of the compounds 1-15 from the fruits of $R$. parviflora.

succedaneaflavanone (10) at RPE-13-10 [11.7 mg, $\mathrm{V}_{\mathrm{e}} / \mathrm{V}_{\mathrm{t}} 0.10-0.11$, TLC (RP-18 $\left.\mathrm{F}_{254} \mathrm{~s}\right) R_{f} 0.68$ in $\mathrm{MeOH}-\mathrm{H}_{2} \mathrm{O}$ (3:1)] and mesuaferrone B (7) at RPE-13-17 [30 mg, $\mathrm{V}_{\mathrm{e}} / \mathrm{V}_{\mathrm{t}} 0.59-0.80$, TLC (RP-18 F $\left.\mathrm{F}_{254} \mathrm{~s}\right)$ $R_{f} 0.55$ in $\left.\mathrm{MeOH}-\mathrm{H}_{2} \mathrm{O}(3: 1)\right]$. Fraction RPE-13-13 $\left(475 \mathrm{mg}, \mathrm{V}_{\mathrm{e}} / \mathrm{V}_{\mathrm{t}}\right.$ $0.16-0.34)$ was applied to ODS c.c. $(\phi 3 \times 4 \mathrm{~cm})$, and eluted with $\mathrm{MeOH}-\mathrm{H}_{2} \mathrm{O}(2: 3,500 \mathrm{~mL} \rightarrow 2: 1,1.5 \mathrm{~L})$ gave rhusflavanone (9) at RPE-13-13-8 [144 mg, $\mathrm{V}_{\mathrm{e}} / \mathrm{V}_{\mathrm{t}}$ 0.17-0.22, TLC (RP-18 $\left.\mathrm{F}_{254} \mathrm{~S}\right) R_{f}$ 0.45 in $\left.\mathrm{MeOH}-\mathrm{H}_{2} \mathrm{O}(2: 1)\right]$. The RPE-15 fraction $\left(2.33 \mathrm{~g}, \mathrm{~V}_{\mathrm{e}} / \mathrm{V}_{\mathrm{t}}\right.$ $0.52-0.54)$ was subjected to an ODS c.c. $(\phi 4 \times 5 \mathrm{~cm})$, and was eluted with $\mathrm{MeOH}-\mathrm{H}_{2} \mathrm{O}(2: 1,4 \mathrm{~L} \rightarrow 1: 1,1 \mathrm{~L})$ gave 13 fractions. The RPE-15-3 fraction (326.0 mg, $\mathrm{V}_{\mathrm{e}} / \mathrm{V}_{\mathrm{t}}$ 0.01-0.09) underwent Sephadex LH-20 c.c. $(\phi 2 \times 45 \mathrm{~cm})$, and was eluted with $\mathrm{MeOH}-$ $\mathrm{H}_{2} \mathrm{O}(1: 1,4.5 \mathrm{~L})$, yielded aureusidin (4) at RPE-15-3-11 [18.4 mg, $\mathrm{V}_{\mathrm{e}} / \mathrm{V}_{\mathrm{t}} 0.65-0.83$, TLC (RP-18 $\left.\mathrm{F}_{254} \mathrm{~S}\right) R_{f} 0.50$, in $\left.\mathrm{MeOH}-\mathrm{H}_{2} \mathrm{O}(2: 1)\right]$. The RPE15-4-3 fraction (88.7 mg, $\left.\mathrm{V}_{\mathrm{e}} / \mathrm{V}_{\mathrm{t}} 0.02-0.04\right)$ was subjected to the Sephadex LH-20 c.c. $(\phi 2.5 \times 35 \mathrm{~cm})$ and eluted with $\mathrm{MeOH}-$ $\mathrm{H}_{2} \mathrm{O}(2: 1,1,200 \mathrm{~mL}$, yielded sulfuretin (3) at RPE-15-4-13-3 [5.6 mg, $\mathrm{V}_{\mathrm{e}} / \mathrm{V}_{\mathrm{t}} 0.25-0.41$, TLC (RP-18 $\left.\mathrm{F}_{254} \mathrm{~s}\right) R_{f} 0.45 \mathrm{MeOH}-\mathrm{H}_{2} \mathrm{O}$ 
Table 1 Inhibition activity of compounds (1-15) from the fruits of $R$. parviflora on LDL-oxidation ${ }^{1}$

\begin{tabular}{|c|c|c|c|}
\hline \multirow{2}{*}{ Compounds } & \multicolumn{2}{|c|}{ LDL-oxidation Inhibition (\%) } & \multirow{2}{*}{$\mathrm{IC}_{50}(\mu \mathrm{M})$} \\
\hline & $100 \mu \mathrm{M} / \mathrm{ml}$ & $10 \mu \mathrm{M} / \mathrm{ml}$ & \\
\hline fustin (1) & $92.6 \pm 0.6$ & $98.5 \pm 1.4$ & 2.4 \\
\hline taxifolin (2) & $99.7 \pm 0.2$ & $91.3 \pm 2.2$ & 0.9 \\
\hline sulfuretin (3) & $97.0 \pm 0.2$ & $101.8 \pm 0.9$ & 2.9 \\
\hline aureusidin (4) & $97.5 \pm 0.1$ & $99.8 \pm 0.2$ & 2.4 \\
\hline agathisflavone (5) & $99.7 \pm 0.2$ & $81.5 \pm 3.1$ & 5.8 \\
\hline cupressuflavone (6) & $99.3 \pm 0.7$ & $68.5 \pm 1.6$ & 7.3 \\
\hline mesuaferrone B (7) & $93.5 \pm 0.2$ & $75.8 \pm 1.2$ & 8.4 \\
\hline rhusflavone (8) & $97.0 \pm 0.0$ & $51.6 \pm 4.7$ & 9.0 \\
\hline rhusflavanone (9) & $99.2 \pm 0.3$ & $57.4 \pm 3.0$ & 10.5 \\
\hline succedaneaflavanone (10) & $87.6 \pm 0.6$ & $14.5 \pm 0.3$ & 58.2 \\
\hline chrysoeriol-7-O- $\beta$-D-glucopyranoside (11) & $96.3 \pm 0.1$ & $72.9 \pm 1.0$ & 7.8 \\
\hline luteolin-7-O- $\beta$-D-glucopyranoside (12) & $97.4 \pm 0.0$ & $94.7 \pm 1.4$ & 1.6 \\
\hline quercetin $3-O-\beta$-D-glucopyranoside (13) & $98.4 \pm 0.5$ & $94.7 \pm 0.2$ & 1.5 \\
\hline quercetin $3-O-\beta-\mathrm{D}$-glactopyranoside (14) & $97.8 \pm 0.9$ & $85.9 \pm 0.6$ & 1.6 \\
\hline quercetin $3-O-\alpha$-L-rhamnopyranoside (15) & $98.3 \pm 0.3$ & $101.8 \pm 0.2$ & 0.8 \\
\hline
\end{tabular}

Data are means \pm SD $(n=3)$.

${ }^{1}$ Positive control of LDL-Oxidation, BHT, showed $\mathrm{IC}_{50}$ value of $2.1 \mu \mathrm{M}$.

(2:1)]. The RPE-15-5 fraction (461.6 mg, $\left.\mathrm{V}_{\mathrm{e}} / \mathrm{V}_{\mathrm{t}} 0.32-0.45\right)$ underwent the Sephadex LH-20 c.c. $(\phi 2.5 \times 45 \mathrm{~cm})$, and was eluted with $\mathrm{MeOH}-\mathrm{H}_{2} \mathrm{O}(2: 1,6 \mathrm{~L})$, gave 13 fractions. Fraction RPE-15-5-10 $\left(81 \mathrm{mg}, \mathrm{V}_{\mathrm{e}} / \mathrm{V}_{\mathrm{t}} 0.53-0.67\right)$ was subjected to ODS c.c. $(\phi 2.5 \times 3 \mathrm{~cm})$ and eluted with $\mathrm{MeOH}-\mathrm{H}_{2} \mathrm{O}(2: 3,250 \mathrm{~mL} \rightarrow 2: 1,300 \mathrm{~mL})$ gave rhusflavone (8) at RPE-15-5-10-6 [66 mg, $\mathrm{V}_{\mathrm{e}} / \mathrm{V}_{\mathrm{t}}$ 0.35-0.46, TLC $\left(\mathrm{RP}-18 \mathrm{~F}_{254} \mathrm{~S}\right) R_{f} 0.55$ in MeOH-H $\left.{ }_{2} \mathrm{O}(3: 1)\right]$. Fraction RPE-15-5-12 (71.4 mg, $\left.\mathrm{V}_{\mathrm{e}} / \mathrm{V}_{\mathrm{t}} 0.83-0.96\right)$ was subjected to the ODS c.c. $(\phi 1.2 \times 4$ $\mathrm{cm})$ and eluted with $\mathrm{MeOH}-\mathrm{H}_{2} \mathrm{O}(1: 2,200 \mathrm{~mL})$, isolated agathisflavone (5) at RPE-15-5-12-3 [60 mg, $\mathrm{V}_{\mathrm{e}} / \mathrm{V}_{\mathrm{t}} 0.24-1.0$, TLC (RP-18 $\left.\left.\mathrm{F}_{254} \mathrm{~S}\right) R_{f} 0.30 \mathrm{MeOH}-\mathrm{H}_{2} \mathrm{O}(2: 1)\right]$. Fraction RPE-15-6 (708 $\mathrm{mg}, \mathrm{V}_{\mathrm{e}} / \mathrm{V}_{\mathrm{t}}$ 0.45-0.87) subjected to Sephadex LH-20 column $(\phi$ $2.5 \times 45 \mathrm{~cm})$ and eluted with $\mathrm{MeOH}-\mathrm{H}_{2} \mathrm{O}(2: 1,5 \mathrm{~L})$, led to isolation of cupressuflavone (6) at RPE-15-6-6 [19 mg, $\mathrm{V}_{\mathrm{e}} / \mathrm{V}_{\mathrm{t}}$ 0.30-0.36, TLC (RP-18 $\left.\mathrm{F}_{254} \mathrm{~S}\right) R_{f} 0.30$ in $\left.\mathrm{MeOH}-\mathrm{H}_{2} \mathrm{O}(3: 1)\right]$.

Further, fraction RPE-17 [2 g, $\left.\mathrm{V}_{\mathrm{e}} / \mathrm{V}_{\mathrm{t}} 0.56-0.60\right]$ was subjected to a Sephadex LH-20 c.c. $(\phi 2.5 \times 45 \mathrm{~cm})$, and eluted with $\mathrm{MeOH}-$ $\mathrm{H}_{2} \mathrm{O}(1: 1,4 \mathrm{~L})$, isolated chrysoeriol-7- $O$ - $\beta$-D-glucopyranoside (11) at RPE-17-21 [44.0 mg, $\mathrm{V}_{\mathrm{e}} / \mathrm{V}_{\mathrm{t}}$ 0.40-0.42, TLC (RP-18 $\left.\mathrm{F}_{254} \mathrm{~S}\right) R_{f}$ 0.62 in $\left.\mathrm{MeOH}-\mathrm{H}_{2} \mathrm{O}(2: 1)\right]$. Fraction RPE-18 (2 g, $\mathrm{V}_{\mathrm{e}} / \mathrm{V}_{\mathrm{t}} 0.60$ $0.61)$ purified by Sephadex LH-20 c.c. $(\phi 2.5 \times 45 \mathrm{~cm})$, and eluted with $\mathrm{MeOH}-\mathrm{H}_{2} \mathrm{O}(1: 1,2 \mathrm{~L})$, resulted in 16 fractions. Fraction RPE-18-8 (90 mg, $\mathrm{V}_{\mathrm{e}} / \mathrm{V}_{\mathrm{t}}$ 0.09-0.16) was subjected to the $\mathrm{SiO}_{2}$ c.c. $(\phi 2 \times 10 \mathrm{~cm})$, and eluted with $\mathrm{CHCl}_{3}-\mathrm{MeOH}(6: 1,300 \mathrm{~mL} \rightarrow 3: 1$, $600 \mathrm{~mL}$ ), isolated luteolin-7-O- $\beta$-D-glucopyranoside (12) at RPE18-8-6 [7.5 mg, $\mathrm{V}_{\mathrm{e}} / \mathrm{V}_{\mathrm{t}}$ 0.13-0.21, TLC $\left(\mathrm{SiO}_{2} \mathrm{~F}_{254}\right) R_{f} 0.55$ in $\left.\mathrm{CHCl}_{3}-\mathrm{MeOH}(5: 1)\right]$. The fraction RPE-18-9 $\left(239 \mathrm{mg}, \mathrm{V}_{\mathrm{e}} / \mathrm{V}_{\mathrm{t}}\right.$ $0.16-0.24)$ subjected to the $\mathrm{SiO}_{2}$ c.c. $(\phi 3 \times 10 \mathrm{~cm})$, and eluted with $\mathrm{CHCl}_{3}-\mathrm{MeOH}(7: 1,200 \mathrm{~mL} \rightarrow 6: 1,700 \mathrm{~mL} \rightarrow 5: 1,700 \mathrm{~mL} \rightarrow 4: 1$, $500 \mathrm{~mL} \rightarrow 1: 1,500 \mathrm{~mL}$ ), isolated quercetin-3- $O$ - $\beta$-D-glucopyranoside (13) at RPE-18-9-4 [21.9 mg, $\mathrm{V}_{\mathrm{e}} / \mathrm{V}_{\mathrm{t}} 0.04-0.06$, TLC $\left(\mathrm{SiO}_{2} \mathrm{~F}_{254}\right) R_{f}$ 0.57 in $\left.\mathrm{CHCl}_{3}-\mathrm{MeOH}-\mathrm{H}_{2} \mathrm{O}(6: 4: 1)\right]$. The fraction RPE-18-10 (510 $\mathrm{mg}, \mathrm{V}_{\mathrm{e}} / \mathrm{V}_{\mathrm{t}}$ 0.24-0.39) subjected to the Sephadex LH-20 c.c. $(\phi$
$2.5 \times 40 \mathrm{~cm})$, and eluted with $\mathrm{MeOH}-\mathrm{H}_{2} \mathrm{O}(1: 3,15 \mathrm{~L})$ to provided 18 fractions, and isolated quercetin-3- $O-\beta$-D-galactopyranoside (14) at RPE-18-10-4 [45.7 mg, $\mathrm{V}_{\mathrm{e}} / \mathrm{V}_{\mathrm{t}}$ 0.17-0.19, TLC (RP-18 $\left.\mathrm{F}_{254} \mathrm{~S}\right) R_{f} 0.55$ in $\left.\mathrm{MeOH}-\mathrm{H}_{2} \mathrm{O}(2: 1)\right]$. Fraction RPE-18-10-11-13 [81 mg, $\mathrm{V}_{\mathrm{e}} / \mathrm{V}_{\mathrm{t}}$ 0.36-0.77] was subjected to the $\mathrm{SiO}_{2}$ c.c. $(\phi 2.2 \times 10$ $\mathrm{cm})$, and eluted with $\mathrm{CHCl}_{3}-\mathrm{MeOH}-\mathrm{EtOH}-\mathrm{H}_{2} \mathrm{O}(34: 3: 3: 2,3 \mathrm{~L})$ gave quercetin-3-O- $\alpha$-L-rhamnopyranoside (15) at RPE-18-1011-13-6 [34 mg, $\mathrm{V}_{\mathrm{e}} / \mathrm{V}_{\mathrm{t}}$ 014-0.29, TLC (RP-18 $\left.\mathrm{F}_{254}\right) R_{f} 0.62$ in $\mathrm{MeOH}-\mathrm{EtOH}-\mathrm{H}_{2} \mathrm{O}$ (9:1:1)].

The structures of isolated compounds 1-15 (Fig. 1) were determined by spectroscopic techniques and by comparison of their spectral data with literature values, and were reported previously by us (Shrestha et al., 2012a; 2012b; 2012c; Shrestha et al., 2013a; 2013b; 2013c). LDL-oxidation assay was carried out using the method described previously (Lee et al., 2009), with butylated hydroxytoluene (BHT) as a positive control. The data of assay are expressed as mean $\pm \mathrm{SD}$ of three replicated experiments (Table 1).

Among the compounds evaluated, several compounds showed competent potency of inhibitory activity on LDL oxidation in comparison to positive control BHT ( $\mathrm{IC}_{50}$ value $2.1 \mu \mathrm{M}$ ). Taxifolin (2) showed significant inhibition of LDL-oxidation $\left(\mathrm{IC}_{50}\right.$ value 0.9 $\mu \mathrm{M})$, the compound was reported previously for its inhibitory effect on hepato-cellular cholesterol biosynthesis in HepG2 cells (Gebhardt, 2003) and inhibition of LDL cholesterol via scavenging of MPO-derived $\mathrm{NO}_{2}$ radicals (Kostyuk et al., 2003). Further, the LDL inhibitory potential of compounds fustin (1), aureusidin (4) and sulfuretin (3) with $\mathrm{IC}_{50}$ values of $2.0,2.9$ and $2.4 \mu \mathrm{M}$ are noteworthy. The extract of Rhus verniciflua with compounds fustin and sulfuretin had been reported for preventing and treating cholesterolemia, hyperlipidemia and fatty liver ( $\mathrm{Na}$ et al., 2013). The biflavonoids, agathisflavone (5), rhusflavone (8), cupressuflavone (6), rhusflavanone (9), mesuaferrone B (7) and succedanea- 
flavanone (10) had $\mathrm{IC}_{50}$ values of 5.8, 7.3, 8.4, 9.0, 10.5 and 58.2 $\mu \mathrm{M}$ respectively. Biflavonoids with both units flavanone had comparatively low inhibitory capacity than those with both units flavone or combination of flavone and flavanone. A bioflavonoid, morelloflavone had been reported for inhibition HMG-CoA reductase (the rate-limiting enzyme) of the cholesterol biosynthetic pathway (Tuansulong et al., 2011). The flavonoid glycosides with the potent inhibition capacity of LDL-oxidation were quercetin 3$O$ - $\alpha$-L-rhamnopyranoside (15), quercetin $3-O$ - $\beta$-glucopyranoside (13), quercetin 3-O- $\beta$-glactopyranoside (14), luteolin-7- $O-\beta$-Dglucopyranoside (12), and chrysoeriol-7- $O$ - $\beta$-D-glucopyranoside (11) with $\mathrm{IC}_{50}$ value of $0.8,1.5,1.6,1.6$ and $7.7 \mu \mathrm{M}$, respectively. Hou et al. (2004) and Shabana et al. (2007) had reported LDLoxidation inhibitory potential of flavonoid glycosides (11-15) and orthodihydroxyl group is regarded as responsible for inhibitory effect (Hou et al., 2004). The inhibitory capacity of bioflavonoids (5-10) and an aurone, aureusidin (4) are reported here for the first time. The anti-hypercholesterolemic effect of biflavonoids by inhibition of LDL oxidation indicates cardiovascular protective anti-hypercholesterolemic potential of $R$. parviflora fruit.

Acknowledgment This work was supported by a grant from the NextGeneration Bio-Green 21 Program (No. PJ009574), Rural Development Administration, Republic of Korea.

\section{References}

Anonymous (2006) The Ayurvedic Pharmacopoeia of India. Part I, Vol. V. Government of India, India.

Dahlöf B (2010) Cardiovascular disease risk factors: epidemiology and risk assessment. Am J Cardiol 105, 3A-9A.

Gebhardt R (2003) Variable influence of kaempferol and myricetin on in vitro hepatocellular cholesterol biosynthesis. Planta Med 69, 1071-4.

Glass CK and Witztum JL (2001) Atherosclerosis. Cell 104, 503-16.

Hansson GK and Hermansson A (2011) The immune system in atherosclerosis. Nat Iimmunol 12, 204-12.

Hou L, Zhou B, Yang L, and Liu ZL (2004) Inhibition of human low density lipoprotein oxidation by flavonols and their glycosides. Chem Phys Lipids 129, 209-19.

Kostyuk VA, Kraemer T, Sies H, and Schewe T (2003) Myeloperoxidase/ nitrite-mediated lipid peroxidation of low-density lipoprotein as modulated by flavonoids. FEBS Lett 537, 146-50.

Lee JK, Cho JG, Song MC, Yoo JS, Lee DY, Yang HJ et al. (2009) Isolation of isoquinoline alkaloids from the tuber of Corydalis turtschaninovii and their inhibition activity on low density lipoprotein oxidation. $J$ Korean Soc Appl Biol Chem 52, 646-54.

Na CS, Yoon SY, Kim JB, Noh HJ, Um NN, Oh GT et al. (2013) A composition for improving or preventing a hyperlipemia and fatty liver comprising Rhus verniciflua stokes. A Korean patent, KR20130040663.

Press JR, Shresttha KK, and Sutton DA (2000) Annotated checklist of the flowering plants of Nepal. The Natural History Museum, London and Central Department of Botany, Nepal.

Shabana MM, El-Sherei MM, Moussa MY, Sleem AA, and Abdallah HM (2007) Investigation of phenolic constituents of Carduncellus eriocephalus Boiss. var. albiflora Gauba and their biological activities. Nat Prod Commun 2, 823-8.

Shrestha S, Lee DY, Park JH, Cho JG, Lee DS, Li B et al. (2013a) Flavonoids from the fruits of Nepalese sumac (Rhus parviflora) attenuate glutamateinduced neurotoxicity in HT22 cells. Food Sci Biotechnol 22, 895-902.

Shrestha S, Lee D-Y, Park J-H, Cho J-G, Lee D-S, Li B et al. (2013b) Phenolic components from Rhus parviflora fruits and their inhibitory effects on lipopolysaccharide-induced nitric oxide production in RAW 264.7 macrophages. Nat Prod Res 27, 2244-7.

Shrestha S, Lee DY, Park JH, Cho JG, Seo WD, Kang HC et al. (2012a) Flavonoid glycosides from the fruit of Rhus parviflora and inhibition of cyclin dependent kinases by hyperin. J Korean Soc Appl Biol Chem 55, 689-93.

Shrestha S, Natarajan S, Park JH, Lee DY, Cho JG, Kim GS et al. (2013c) Potential neuroprotective flavonoid-based inhibitors of CDK5/p25 from Rhus parviflora. Bioorg Med Chem Lett 23, 5150-4.

Shrestha S, Park JH, Lee DY, Cho JG, Cho S, Yang HJ et al. (2012b) Rhus parviflora and its biflavonoid constituent, rhusflavone, induce sleep through the positive allosteric modulation of $\mathrm{GABA}_{\mathrm{A}}$-benzodiazepine receptors. J Ethnopharmacol 142, 213-20.

Shrestha S, Park JH, Lee DY, Cho JG, Seo WD, Kang HC et al. (2012c) Cytotoxic and neuroprotective biflavonoids from the fruit of Rhus parviflora. J Korean Soc Appl Biol Chem 55, 557-62.

Tuansulong KA, Hutadilok-Towatana N, Mahabusarakam W, Pinkaew D, and Fujise K (2011) Morelloflavone from Garcinia dulcis as a novel biflavonoid inhibitor of HMG-CoA reductase. Phytother Res 25, 424-8. 